\title{
“New Homeopathic Medicines" proposal: a database made available in three free-access bilingual digital books
}

\author{
Marcus Zulian Teixeira1*
}

\section{INTRODUCTION}

Homeopathy, a Brazilian medical specialty since 1980, is based on four assumptions, with several lines of research attesting its scientific validity:

(1) principle of therapeutic similitude,

(2) testing of medicines on healthy individuals (homeopathic pathogenetic trials),

(3) prescription of individualized medicines, and

(4) the use of serially diluted and agitated medicines (ultra-diluted and potentized doses). Although much relevance is attributed to ultra-diluted doses, the first two assumptions represent the proper foundation of the homeopathic epistemological model.

In the development of the homeopathic approach to treatment, Samuel Hahnemann (1755-1843) had resource to the phenomenological method of qualitative research to describe the effects of contemporary drugs on the human physiology and ground the therapeutic similitude principle. Hahnemann noted that medicines cause signs and symptoms in healthy individuals similar to the ones exhibited by patients cured with the same medicines. He surveyed the literature and found hundreds of clinical reports by doctors from all times and places, involving many different categories of drugs, which confirmed his finding.

With these evidences and through the application of Aristotelian inductive reasoning (modus ponens), Hahnemann outlined the homeopathic healing principle: "for any medicine to cure symptoms in the sick, it must induce similar symptoms in the healthy." By developing a physiological explanation for such "natural healing law," he grounded the therapeutic similitude principle on the "primary action of drugs" and the consequent and opposite "secondary action or vital reaction of the body":
"Every agent that acts upon the vitality, every medicine, deranges more or less the vital force, and causes a certain alteration in the health of the individual for a longer or a shorter period. This is termed primary action. [...] To its action our vital force endeavors to oppose its own energy. This resistant action is a property, is indeed an automatic action of our life-preserving power, which goes by the name of secondary action or counteraction" (Organon of medicine, $\$ 63)^{2}$.

Exemplifying this phenomenon, Hahnemann described the primary actions of drugs and the consequent secondary reaction of the body in several physiological systems (Table 1), characterized by the effects opposite to the primary physiological changes (Organon of medicine, $\$ 59,65)^{2}$. The latter leads the body back to the state previous to intervention ("life-preserving power," i.e., modern homeostasis).

Pointing to the unpleasant results of indiscriminate use of medicines with contrary action to the symptoms of disease (Organon of medicine, \$59-61) ${ }^{2}$, Hahnemann called the attention to the fact that the secondary action (vital reaction) of the body might cause undesirable effects ("a relapse - indeed, a palpable aggravation of the malady"), validating homeopathic treatment (principle of similitude) through resource to Aristotelian deductive reasoning (modus tollens or affirmation through negation, i.e., the null hypothesis of modern biostatistics).

Since the secondary reaction of the body (opposed to the primary action of the drug) could occur with any category of drugs independently from the dose (ponderable or ultra-diluted), Hahnemann raised the similitude principle to the status of "natural phenomenon" (Organon of medicine, $\$ 58,61$, $110-112)^{2}$.

Through administration to the sick of the very medicines that induce similar symptoms in the healthy on "homeopathic pathogenetic trials" (similar to our phase I clinical trials) ${ }^{3}$, the

'Universidade de São Paulo, School of Medicine - São Paulo (SP), Brazil.

*Corresponding author: marcus@homeozulian.med.br

Conflicts of interest: the authors declare there are no conflicts of interest. Funding: none.

Received on May 08, 2021. Accepted on August 16, 2021. 
Table 1. Hahnemann's examples of primary action of drug and secondary action (vital reaction) of the body.

\begin{tabular}{l|c|c} 
Drugs & Primary action of drug & Secondary action of the body \\
Coffee & Excessive vivacity; sleepiness, or insomnia & Sluggishness and drowsiness; somnolence \\
\hline Opium & Profound and stupefied sleep & Sleepiness or insomnia \\
\hline Opium & Constipation & Diarrhea \\
\hline Opium & Analgesia & Hyperalgesia \\
\hline Purgatives or laxatives & Diarrhea & Constipation \\
\hline Cantharides & Polyuria & Oliguria or anuria \\
\hline
\end{tabular}

aim of therapeutic similitude is to trigger a curative homeostatic reaction by making the body to react against its own disorders. It should be noticed that the "secondary or vital reaction" designate the ability of living beings to maintain the internal environment constant ("life-preserving power" or homeostasis) through automatic self-adjustment of the physiological processes, ranging from simple cell mechanisms to complex mental functions.

\section{SCIENTIFIC BASIS OF THE PRINCIPLE OF SIMILITUDE IN MODERN PHARMACOLOGY}

In modern scientific terms, Hahnemann's "primary action" corresponds to the "therapeutic, adverse, and side effects" of conventional drugs. In turn, the homeopathic "secondary action or vital reaction" corresponds to the "rebound effect" or "paradoxical reaction" of the body that follows discontinuation of countless categories of drugs that work in a manner opposed (palliative or antagonistic) to the symptoms of disease.

"Rebound effect" is defined as the production of increased negative symptoms when the primary effect of a drug has passed or the patient no longer responds to the drug; if a drug produces a rebound effect, the condition that was used to treat may come back even stronger when the drug is discontinued or lost its effectiveness. Analogously, "paradoxical reaction" is a response opposed to the foreseen effect of a drug. Briefly, we might understand rebound effect as an automatic and instinctive manifestation of the homeostatic mechanisms aiming at reestablishing the original state, altered by the primary action of drugs, resulting in an opposed effect and contrary to the expected one.

The rebound effect appears following discontinuation or withdrawal of drugs, causing manifestations with stronger intensity and/or more frequent than the ones originally suppressed (which distinguish it from relapse of the original disease following the end of the primary action of drugs). These manifestations appear at variable intervals and also have variable duration. As a feature intrinsic to the phenomenon, one should consider a minimum interval of time to have a sound notion of the true magnitude of the phenomenon; this minimum interval corresponds to the full metabolism of drugs or the absence of therapeutic effect (biological half-life). While discontinuation is a requisite for the rebound effect to manifest - since the primary action continues as long as receptors are bounded to the drug - some studies showed that it might also occur along the course of treatment, in cases of therapeutic failure or development of tolerance, tachyphylaxis, or receptor desensitization. In turn, drug tapering avoids abrupt discontinuation and thus minimizes the occurrence of the rebound effect.

Given the epistemological relevance of therapeutic similitude vis-à-vis the remainder of homeopathic assumptions, since 1998, following the Aristotelian deductive reasoning employed by Samuel Hahnemann to scientifically support the law of similars, we have been bridging the gap between homeopathic and conventional pharmacology through the systematic study of the rebound effect of modern drugs ${ }^{4-7}$, scientifically confirming the homeopathic postulate (primary action of the drug followed by secondary and opposite reaction of the body) and the homeopathic healing principle.

Tables 2 and 3 list the examples with various categories of drugs illustrating the universal nature of the rebound effect and the principle of similitude ${ }^{4-7}$.

These clinical and experimental pharmacological evidences ${ }^{4-7}$ show that the characteristics of the rebound effect are similar to the homeopathic secondary action or reaction (Organon of medicine, $\$ 59,64,69)^{2}$ :

(1) it induces a body reaction opposed to and of greater intensity compared to the primary action of drugs;

(2) it takes place after the end of the primary action of the drug, and as automatic manifestation of the body;

(3) it does not depend on the type of drug, dose, treatment duration, or category of symptoms (disease);

(4) its magnitude is proportional to the primary action of the drug; and

(5) it appears in susceptible individuals only (idiosyncrasy). 
Table 2. Primary action (therapeutic effect) of modern drugs followed by secondary and opposite reaction (rebound effect) of the body

\begin{tabular}{|c|c|}
\hline Primary action (therapeutic effect) of modern drugs & Secondary reaction (rebound effect) of the body \\
\hline $\begin{array}{l}\text { Antiarrhythmic action (adenosine, amiodarone, beta- } \\
\text { blockers, calcium channel blockers, disopyramide, } \\
\text { flecainide, lidocaine, mexiletine, moricizine, and } \\
\text { procainamide) }\end{array}$ & $\begin{array}{l}\text { Rebound exacerbation of basal arrhythmia after } \\
\text { discontinuation or withdrawal of drug }\end{array}$ \\
\hline $\begin{array}{l}\text { Antianginal action (nitrates, beta-blockers, and calcium } \\
\text { channel blockers) }\end{array}$ & $\begin{array}{l}\text { Paradoxical increase of frequency and/or intensity of } \\
\text { angina pectoris }\end{array}$ \\
\hline $\begin{array}{l}\text { Hypotension action (alfa-2 agonists, beta-blockers, ACE } \\
\text { inhibitors, MAO inhibitors, nitrates, sodium nitroprusside, } \\
\text { and hydralazine) }\end{array}$ & Paradoxical arterial hypertension \\
\hline $\begin{array}{l}\text { Antithrombotic action (argatroban, bezafibrate, heparin, } \\
\text { salicylates, warfarin, and clopidogrel) }\end{array}$ & Rebound thromboembolism \\
\hline Pleiotropic (vasoprotective) action (statins) & Paradoxical endothelial dysfunction \\
\hline $\begin{array}{l}\text { Anxiolytic action (barbiturates, benzodiazepines, and } \\
\text { carbamates) }\end{array}$ & Paradoxical anxiety \\
\hline $\begin{array}{l}\text { Sedative-hypnotic action (barbiturates, benzodiazepines, } \\
\text { morphine, promethazine, and zopiclone) }\end{array}$ & $\begin{array}{l}\text { Increased rebound of agitation, nervousness, restlessness, } \\
\text { and irritability }\end{array}$ \\
\hline $\begin{array}{l}\text { Antidepressant action (tricyclic, MAO inhibitors, and } \\
\text { selective serotonin reuptake inhibitors) }\end{array}$ & Paradoxical increase of depressive symptoms \\
\hline $\begin{array}{l}\text { Antipsychotic action (clozapine, phenothiazines, } \\
\text { haloperidol, and pimozide) }\end{array}$ & Rebound exacerbation of psychotic manifestations \\
\hline
\end{tabular}

Table 3. Primary action (therapeutic effect) of modern drugs followed by secondary and opposite reaction (rebound effect) of the body.

\begin{tabular}{l} 
Primary action (therapeutic effect) of modern drugs \\
Analgesic action (caffeine, calcium channels blockers, \\
clonidine, ergotamine, methysergide, opiates, and salicylates) \\
\hline Anti-inflammatory action (steroids, ibuprofen, \\
indomethacin, paracetamol, and salicylates)
\end{tabular}

Diuretic action (furosemide, torasemide, and triamterene)
Secondary reaction (rebound effect) of the body

Hyperalgesia paradoxical after discontinuation or withdrawal of drug

Rebound increase of inflammation

Paradoxical retention of sodium and potassium with consequent increase of blood volume and arterial pressure

\section{Rebound bronchoconstriction}

Paradoxical increase in the production of hydrochloric acid and gastrin

Rebound increase of osteoclastic activity causing paradoxical atypical fractures

Paradoxical effect on the inflammatory and immune response of drug
Despite this idiosyncratic nature of the rebound effect which appears in a small proportion of individuals - scientific evidences point to the occurrence of severe and fatal events as a result of the paradoxical reaction of the body following discontinuation of different categories of drugs ${ }^{5-7}$. This corroborates the magnitude of the phenomenon, the need to be duly known by health care providers, and the benefits of its therapeutic application according to the similitude principle. 


\section{"NEW HOMEOPATHIC MEDICINES" PROPOSAL: USE OF MODERN DRUGS ACCORDING TO THE PRINCIPLE OF SIMILITUDE}

The basic assumption underlying the homeopathic healing principle is the use of drugs that cause pathogenetic manifestations (signs, symptoms, and physiological or pathological effect) similar to the disorders to be cured. A similar use might be made of any type of drug (natural or synthetic) and in any dose (ponderable or ultra-diluted), provided the therapeutic similitude principle is observed. Thus, modern drugs might be used according to the homeopathic assumptions, provided they induce primary effects (therapeutic, adverse, or side effects) similar to the full set of characteristic signs and symptoms exhibited by patients.

Since 2003, we advocate the use of the rebound effect of modern drugs with curative intent $t^{8-13}$. For this purpose, patients are given drugs in ultra-diluted doses, which caused a similar set of adverse events aiming at stimulating the homeostatic reaction of the body against its own disorders.

To make this idea feasible, a Homeopathic Materia Medica of Modern Drugs was prepared, in which all the primary or pathogenetic effects (therapeutic, adverse, and side effects) of 1,250 modern drugs described in The United States Pharmacopeia Dispensing Information (USPDI) ${ }^{14}$ are organized according to an anatomical-functional distribution following the format of the traditional Homeopathic Materia Medica.

To facilitate the choice of the individualized medicine to be prescribed, according to the full set of similar symptoms, a Homeopathic Repertory of Modern Drugs was prepared. Here, pathogenetic effects and the corresponding drugs are organized according to the format of the traditional homeopathic repertories, following the aforementioned anatomical-functional distribution.

The proposal entitled "New Homeopathic Medicines: use of modern drugs according to the principle of similitude" $8-13$ was described and systematized in a database composed of three distinct works:

(1) Scientific Basis of the Principle of Similitude in Modern Pharmacology,

(2) Homeopathic Materia Medica of Modern Drugs, and

(3) Homeopathic Repertory of Modern Drugs.

\section{"NEW HOMEOPATHIC MEDICINES" PROPOSAL: A DATABASE MADE AVAILABLE IN THREE FREE-ACCESS BILINGUAL DIGITAL BOOKS}

In 2010, in order to allow everyone access to this proposal and its database, these three digital works, totaling thousands of pages, were freely available on a bilingual website (Portuguese and English) prepared on the Adobe Flash Player platform, enabling that this clinical protocol could be analyzed and used by all homeopaths.

Unfortunately, as of 2021, the Adobe Flash Player platform was blocked without offering an alternative to it, preventing colleagues from continuing to have access to that proposal and its database.

Offering an alternative to maintaining this proposal, we have made available the three mentioned works in the format of free-access digital books (PDF), in Portuguese ${ }^{15-17}$ and English ${ }^{18-20}$ editions. These two editions of three books were indexed in the Virtual Health Library (PAHO, WHO, and BIREME) and are currently accessible to all interested parties:

\section{Content of the Portuguese edition ${ }^{15-17}$}

- Fundamentaçáo científica do princípio da similitude na farmacologia moderna ${ }^{15}$;

- Matéria médica homeopática dos fármacos modernos ${ }^{16}$;

- Repertório homeopático dos fármacos modernos ${ }^{17}$.

\section{Content of the English edition ${ }^{18-20}$}

- Scientific basis of the principle of similitude in modern pharmacology ${ }^{18}$;

- Homeopathic materia medica of modern drugs ${ }^{19}$;

- Homeopathic repertory of modern drugs ${ }^{20}$.

\section{CONCLUSIONS}

To test this proposal, we recently developed a clinical research protocol for the use of potentized estrogen (17- $\beta$ estradiol) for the treatment of endometriosis-associated pelvic pain, since estrogen causes endometrial hyperplasia or proliferation as adverse event ${ }^{21}$. Reporting significant improvement versus placebo in relation to pain, depression, and quality of life ${ }^{22}$, this study suggests the validity of this clinical and scientific proposal.

Nevertheless, for this method to be included in homeopathic standard practice, homeopaths need to unite around this project: physicians should apply it in clinical practice and describe the results (case reports), pharmacists should prepare the corresponding homeopathic potentized medicines, and the researchers should design clinical protocols. 


\section{REFERENCES}

1. Teixeira MZ. Special Dossier: "Scientific Evidence for Homeopathy". Rev Assoc Med Bras. 2018;64(2):93-4. https:// doi.org/10.1590/1806-9282.64.02.93

2. Hahnemann S. Organon of medicine [internet]. 6th ed. São Paulo: Editora Organon Ltda; 1998. [cited on May 8, 2021]. Available from: http://www.homeoint.org/books/hahorgan/index.htm

3. Teixeira MZ. Protocolo de experimentação patogenética homeopática em humanos. Rev Med (São Paulo). 2013;92(4):242-63. https://doi.org/10.11606/issn.16799836.v92i4p242-263

4. Teixeira MZ. Similitude in modern pharmacology. Br Homeopath J. 1999;88(3):112-20. https://doi.org/10.1054/homp.1999.0301

5. Teixeira MZ. Similia similibus curentur: o princípio de cura homeopático fundamentado na farmacologia moderna. Rev Med (São Paulo). 2013;92(3):183-203. https://doi. org/10.11606/issn.1679-9836.v92i3p183-203

6. Teixeira MZ. Rebound effects of modern drugs: serious adverse events unknown by health professionals. Rev Assoc Med Bras. 2013;59(6):629-38. https://doi.org/10.1016/j. ramb.2013.05.003

7. Teixeira MZ. Scientific basis of the homeopathic healing principle in modern pharmacology. Rev Homeopatia (São Paulo). 2017;80(3-4):36-81. http://revista.aph.org.br/index. php/aph/article/view/408

8. Teixeira MZ. Homeopathic use of modern medicines: utilisation of the curative rebound effect. Med Hypotheses. 2003;60(2):27683. https://doi.org/10.1016/s0306-9877(02)00386-9

9. Teixeira MZ. New homeopathic medicines: use of modern drugs according to the principle of similitude. Homeopathy. 2011;100(4):244-52. https://doi.org/10.1016/j. homp.2011.01.002

10. Teixeira MZ. Homeopathic use of modern drugs: therapeutic application of the organism paradoxical reaction or rebound effect. Int J High Dilution Res. 2011;10(37):338-52. https:// highdilution.org/index.php/ijhdr/article/view/456

11. Teixeira MZ. 'New Homeopathic Medicines' database: A project to employ conventional drugs according to the homeopathic method of treatment. EUJIM. 2013;5(3):270-8. https://doi. org/10.1016/j.eujim.2013.01.001

12. Teixeira MZ. 'Paradoxical pharmacology': therapeutic strategy used by the 'homeopathic pharmacology' for more than two centuries. Int J High Dilution Res. 2014;13(48):207-26. https:// highdilution.org/index.php/ijhdr/article/view/714
13. Teixeira MZ. Therapeutic use of the rebound effect of modern drugs: "New homeopathic medicines". Rev Assoc Med Bras. 2017;63(2):100-8. https://doi.org/10.1590/18069282.63.02.100

14. The United States Pharmacopeial Convention. The United States pharmacopeia dispensing information. 24th ed. Easton: Mack Printing Co; 2004.

15. Teixeira MZ. Fundamentação científica do princípio da similitude na farmacologia moderna. 2nd ed. São Paulo: edição do autor; 2021[cited on May 8, 2021]. 387p. Available from: https:// pesquisa.bvsalud.org/portal/resource/pt/biblio-1148202

16. Teixeira MZ. Matéria médica homeopática dos fármacos modernos. 2nd ed. São Paulo: edição do autor; 2021[cited on May 08, 2021]. 1309p. Available from: https://pesquisa. bvsalud.org/portal/resource/pt/biblio-1148215

17. Teixeira MZ. Repertório homeopático dos fármacos modernos. 2nd ed. São Paulo: edição do autor; 2021[cited on May 08, 2021]. 780 p. Available from: https://pesquisa.bvsalud.org/ portal/resource/pt/biblio-1148263.

18. Teixeira MZ. Scientific basis of the principle of similitude in modern pharmacology. 2nd edition. 2nd ed. São Paulo: author's edition; 2021[cited on May 08, 2021]. 477 p. Available from: https://pesquisa.bvsalud.org/portal/resource/en/biblio-1148205.

19. Teixeira MZ. Homeopathic materia medica of modern drugs. 2nd edition. São Paulo: 2nd ed. São Paulo: author's edition; 2021[cited on May 08, 2021]. 1336 p. Available from: https:// pesquisa.bvsalud.org/portal/resource/en/biblio-1148219.

20. Teixeira MZ. Homeopathic repertory of modern drugs. 2nd edition. São Paulo: Marcus Zulian Teixeira, 20212nd ed. São Paulo: author's edition; 2021[cited on May 08, 2021]. 808 p. Available from: https://pesquisa.bvsalud.org/portal/resource/ en/biblio-1148266.

21. Teixeira MZ, Podgaec S, Baracat EC. Protocol of randomized controlled trial of potentized estrogen in homeopathic treatment of chronic pelvic pain associated with endometriosis. Homeopathy. 2016;105(3):240-9. https://doi.org/10.1016/j. homp.2016.03.002

22. Teixeira MZ, Podgaec S, Baracat EC. Potentized estrogen in homeopathic treatment of endometriosis-associated pelvic pain: a 24-week, randomized, double-blind, placebo-controlled study. Eur J Obstet Gynecol Reprod Biol. 2017;211:48-55. https://doi.org/10.1016/j.ejogrb.2017.01.052 